\title{
Estimating the Impact of Drought on Groundwater Resources of the Marshall Islands
}

\author{
Brandon L. Barkey ${ }^{1,2, *}$ and Ryan T. Bailey ${ }^{2}$ \\ 1 JUB Engineers, 1047 S 100 W \#180, Logan, UT 84321, USA \\ 2 Department of Civil and Environmental Engineering, Colorado State University, 1372 Campus Delivery, \\ Fort Collins, CO 80523, USA; rtbailey@engr.colostate.edu \\ * Correspondence: bbarkey@jub.com; Tel.: +1-435-535-5489
}

Academic Editors: Robert Puls and Robert Powell

Received: 18 October 2016; Accepted: 23 December 2016; Published: 10 January 2017

\begin{abstract}
Groundwater resources of small coral islands are threatened due to short-term and long-term changes in climate. A significant short-term threat is El Niño events, which typically induce a severe months-long drought for many atoll nations in the western and central Pacific regions that exhausts rainwater supply and necessitates the use of groundwater. This study quantifies fresh groundwater resources under both average rainfall and drought conditions for the Republic of Marshall Islands (RMI), a nation composed solely of atolls and which is severely impacted by El Niño droughts. The atoll island algebraic model is used to estimate the thickness of the freshwater lens for 680 inhabited and uninhabited islands of the RMI, with a focus on the severe 1998 drought. The model accounts for precipitation, island width, hydraulic conductivity of the upper Holocene-age sand aquifer, the depth to the contact between the Holocene aquifer and the lower Pleistocene-age limestone aquifer, and the presence of a reef flat plate underlying the ocean side of the island. Model results are tested for islands that have fresh groundwater data. Results highlight the fragility of groundwater resources for the nation. Average lens thickness during typical seasonal rainfall is approximately $4 \mathrm{~m}$, with only $30 \%$ of the islands maintaining a lens thicker than $4.5 \%$ and $55 \%$ of the islands with a lens less than $2.5 \mathrm{~m}$ thick. Thicker lenses typically occur for larger islands, islands located on the leeward side of an atoll due to lower hydraulic conductivity, and islands located in the southern region of the RMI due to higher rainfall rates. During drought, groundwater on small islands ( $<300 \mathrm{~m}$ in width) is completely depleted. Over half $(54 \%)$ of the islands are classified as "Highly Vulnerable" to drought. Results provide valuable information for RMI water resources planners, particularly during the current 2016 El Niño drought, and similar methods can be used to quantify groundwater availability for other atoll island nations, including the Federated State of Micronesia, Republic of Maldives, and Republic of Kiribati.
\end{abstract}

Keywords: groundwater; freshwater lens; Marshall Islands; drought; groundwater management; modeling; atolls; climate change; sea-level rise

\section{Introduction}

Many small island nations face impending depletion of fresh groundwater resources due to population growth, intense El Niño-induced droughts, and long-term sea level rise. Many nations in the Pacific and Indian Ocean are composed principally or exclusively of atolls, which consist of a circular to elliptical chain of small coral islands that surround a shallow lagoon. Some of these nations include the Republic of Maldives in the Indian Ocean, and the Federated States of Micronesia, the Republic of Marshall Islands (RMI), and the Republic of Kiribati in the western Pacific Ocean. Of the four categories of climate change vulnerability, both the Marshall Islands and Kiribati are listed under the "Profound Impacts" category, i.e., the countries "may cease to exist in the event of worst-case 
scenarios" [1]. Shoreline recession due to long-term sea level rise creates a thinner lens of fresh groundwater [2-4]. In addition, prolonged drought is the greatest immediate threat to diminishing groundwater supply on small islands and can result in a state of emergency for these nations [5-8].

The Marshall Islands in particular are acutely affected by intense El Niño-induced droughts. The entire population of 55,000 inhabitants is spread across 1100 individual atoll islands and islets, with each island vulnerable to intense drought and the associated depletion of rainwater supply and thinning of the freshwater lens [9]. In 2013, 11,000 Marshallese suffered from food and water shortages, with the atolls located in the northern region of the Marshall Islands impacted the most. The current drought of 2016 is considered one of the strongest on record, as rainwater in rooftop catchment systems is depleted and groundwater wells are brackish, leading to severe water rationing across the nation. The government declared a state of national emergency in February 2016, with the United States government declaring the situation a natural disaster and therefore allowing for emergency funding for the nation.

Groundwater is most extensively used during drought due to depletion of rainwater storage. Therefore, an assessment of groundwater supply during drought conditions is imperative for current and future water resources management for specific islands or for the entire geographic region of the Marshall Islands. Many field and numerical modeling studies have assessed groundwater resources of individual islands in the Marshall Islands, including Arno Atoll [10]; Utirik, Taka, Likiep, Ailuk, Law, Kwajalein, Uelang, Wotho, Ujae, Tangi, and Bikar Atolls [11]; Kwajalein Island, Kwajalein Atoll [12]; Enjebi Island, Enewetak Atoll [13-15]; Laura Island, Majuro Atoll [16,17]; and Roi-Namur Island, Kwajalein Atoll [18]. However, none have provided a comprehensive assessment of groundwater availability of Marshallese islands, and only focused on the effect of drought [17].

The objective of this study is to estimate groundwater availability of the atoll islands of the Marshall Islands under extreme drought conditions. Groundwater availability under average rainfall conditions also is estimated to provide a context for groundwater depletion during droughts. The supply of groundwater is estimated using an algebraic model created for freshwater lenses of small coral islands, which has been tested for other atoll nations, including the Federated States of Micronesia and the Republic of Maldives [19,20]. Results are obtained using the rainfall data during the 1997-1999 time period, which experienced an El Niño drought as severe as the current 2015-2016 drought. The model is applied to 680 islands for average rainfall conditions, and 83 islands for drought conditions, with islands selected from each of the 29 atolls of the Marshall Islands. Results can be used to determine the severity of impending groundwater depletion during a drought, and thereby assist with water resources planning and management. In general, the methodology presented in this paper can be used for other coral islands and atoll nations throughout the Pacific Ocean.

\section{Description of the Study Area: Republic of Marshall Islands}

\subsection{Geography}

The geographic location of the Marshall Islands in the western Pacific is shown in Figure 1A, along with other atoll nations (Federated States of Micronesia, Republic of Kiribati). The republic extends over a distance of approximately $1100 \mathrm{~km}$ and encompasses an ocean area of about 500,000 $\mathrm{km}^{2}$. The total land surface area is only about $175 \mathrm{~km}^{2}$ [21]. A map of the Marshall Islands (Figure 1B) shows the 29 atolls of the nation, with the capital atoll Majuro (Figure 2A) shown in red lettering. The atolls are grouped into two parallel "chains": the Ralik Chain (sunset) in the west, and the Ratak (sunrise) Chain in the east. Each atoll consists of at least several coral islands surrounding a shallow lagoon. The majority of the population lives on four atolls: Majuro (capital), Kwajalein, Jaluit, and Arno. The population has increased from 30,000 in 1980 to the current population of 55,000.

The maximum elevation of any island is about $3 \mathrm{~m} \mathrm{[14].} \mathrm{The} \mathrm{average} \mathrm{width} \mathrm{of} \mathrm{each} \mathrm{island} \mathrm{is}$ approximately $300 \mathrm{~m}$, ranging from 100 to about $1700 \mathrm{~m}$. Laura Island, the main island of Majuro Atoll, has a maximum lagoon-to-ocean width of $1200 \mathrm{~m}$. The size of each island is strongly dependent on the 
northeastern prevailing winds (see Figure 2A), with islands on the windward side of each atoll much smaller than the islands on the leeward side of each atoll due to high-energy waves from the northeast.

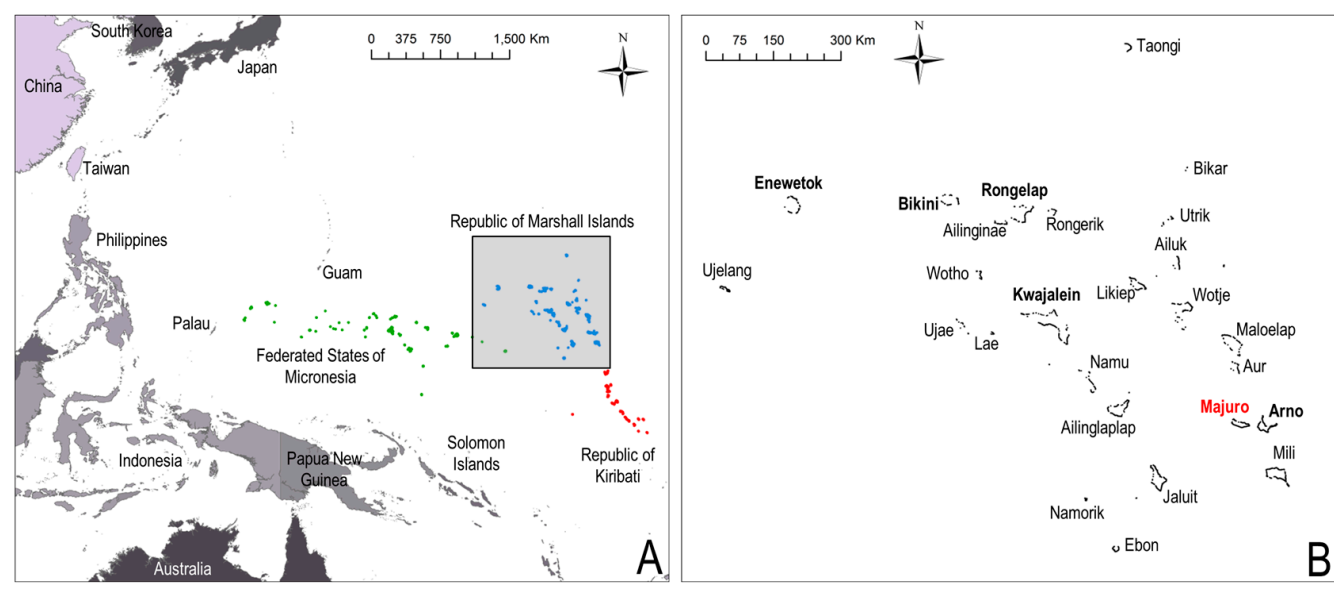

Figure 1. (A) Map of the western Pacific Ocean, showing the atoll nations of the Federated States of Micronesia (green), the Republic of Kiribati (red), and the Republic of Marshall Islands (blue); (B) a map of the Republic of Marshall Islands, with the capital island of Majuro shown in bolded red and all atolls on which groundwater studies have been conducted shown in bold.

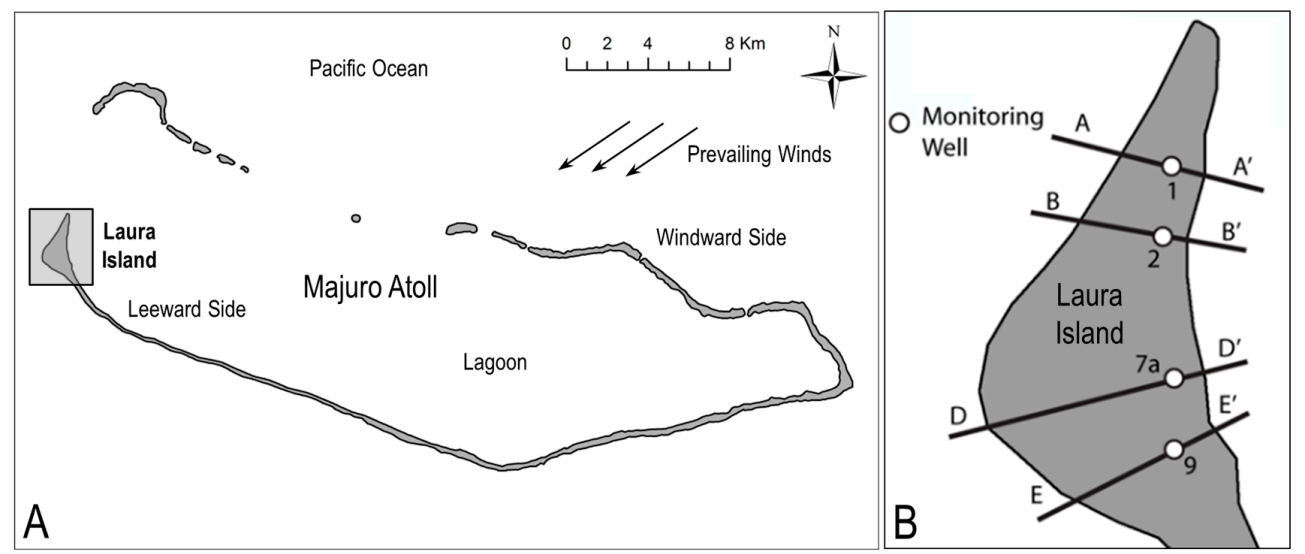

Figure 2. (A) Majuro Atoll, showing the direction of prevailing winds and the windward and leeward sides of the atoll; and (B) a close-up map of Laura Island and the location of the four monitoring wells. Data from the monitoring wells during the 1998-1999 El Niño drought are used in this study to corroborate the algebraic model for drought periods.

\subsection{Climate and Water Resources}

The average annual temperature is $27.2{ }^{\circ} \mathrm{C}$, and the average annual rainfall increases from northwest to southeast: Enewetak (northwest) has an average of $150 \mathrm{~cm} /$ year, Kwajalein (central) has an average of $260 \mathrm{~cm} /$ year, and Majuro (southeast) has an average of $356 \mathrm{~cm} /$ year. Approximately $75 \%$ of rainfall occurs during the wet season from June to December [21], with rainfall captured by guttered rooftop catchment systems. Groundwater typically is used during the dry season from January to May, when rainwater storage tanks are depleted.

Rainfall not captured by rooftop systems or evaporated can percolate through the thin vadose zone and recharge the fresh groundwater lens (see Figure 3). The lens resides in a sand aquifer of Holocene age, which sits atop a karstified limestone aquifer of Pleistocene age. The two units are separated by a solution discontinuity termed the "Thurber Discontinuity", which typically is 15-25 m below sea level $[14,22]$. This "dual aquifer" conceptualization of atoll island hydrogeology is based 
on field studies in the Marshall Islands on Arno [10], Bikini and Enewetak [13,23], Majuro [16], and Kwajalein [12], besides islands in the nearby Federated States of Micronesia [22,24]. The Pleistocene aquifer is one to two orders of magnitude more permeable than the Holocene aquifer [23]. A lithified reef plate also extends beneath the seaward side of the island.

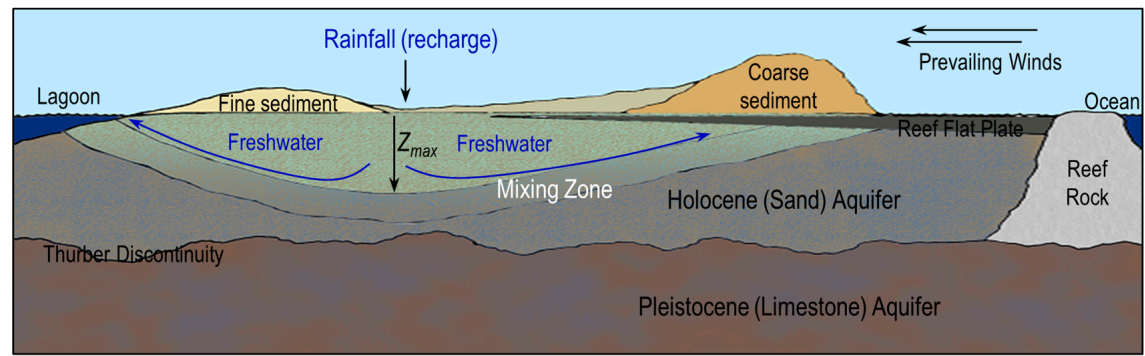

Figure 3. Geologic cross section of a typical atoll island from the lagoon side to the ocean side [16,24]. The lens thickness at the center of the island $\left(Z_{\max }\right)$, the primary output from the algebraic model, also is shown in the figure.

The thickness of the freshwater lens is often used as a surrogate for groundwater availability on coral islands. The lens thickness $Z_{\max }$ (see Figure 3) is controlled principally by island width, recharge from rainfall, the hydraulic conductivity $K$ of the Holocene aquifer, the depth to the Thurber Discontinuity $Z_{T D}$, the presence of the reef flat plate, and drought. Lens thickness for atoll islands in the Pacific and Indian Ocean generally ranges from a few meters to $20 \mathrm{~m}$, limited by the Thurber Discontinuity as any freshwater below the discontinuity becomes salinized. Holocene aquifer $K$ is strongly dependent on the position of the island in relation to the prevailing winds $[21,25,26]$, with islands on the windward side of the atoll possessing much more permeable sediment than islands on the leeward side. Based on comparisons between numerical modeling simulations and observed lens thickness, $K$ for leeward and windward islands in the western Pacific is estimated to be $50 \mathrm{~m} /$ day and $400 \mathrm{~m} /$ day, respectively [26]. Drought induced by the El Niño Southern Oscillation (ENSO) can quickly deplete groundwater resources. During the 1997-1999 severe drought, groundwater supply depleted more than 50\% on Laura Island, Majuro Atoll [18].

\section{Assessing Groundwater Availability}

\subsection{Algebraic Model for Coral Island Freshwater Lens Thickness}

The simulator tool used to estimate lens thickness of atoll islands in the Marshall Islands under both average rainfall conditions and under extreme drought conditions is the algebraic model developed by [27]. The model was developed using simulation results from the SUTRA (Saturated-Unsaturated Transport) [28] density-dependent groundwater flow and transport model applied to atoll islands with hydrogeology represented by the conceptual model summarized in Figure 3 [26]. Relationships between lens thickness $Z_{\max }$ and recharge, island width, Holocene aquifer $K, Z_{T D}$, and the presence and absence of the reef flat plate were quantified using a comprehensive set of transient numerical modeling simulations, leading to the following algebraic model:

$$
Z_{\text {max }}=Z_{L i m} \cdot\left(1-e^{-b R}\right) \cdot S \cdot C \cdot D
$$

where $R$ is annual average rainfall ( $\mathrm{m} /$ year) for the island, $b(-)$ is a fitting parameter dependent on island width, $S(-)$ is the hydraulic conductivity factor, $C(-)$ is the reef flat plate factor, $D(-)$ is a time-dependent drought factor, and $Z_{\text {Lim }}$ is the limiting thickness of the lens based on island width and $Z_{T D}$, given as:

$$
Z_{\text {Lim }}=y_{o}+\left(Z_{T D}-y_{o}\right)\left(1-e^{-d \cdot w}\right)
$$


where $y_{0}$ and $d$ are constants ( -16.07 and 0.0075 , respectively) and $w$ is the cross-section width of the island (m) from the lagoon side to the ocean side. The freshwater limit was set to $500 \mathrm{mg} / \mathrm{L}$ Chloride, approximately $2.5 \%$ of the salt in seawater, in the SUTRA simulations, and hence this coincides with the base of the freshwater lens represented by $Z_{\max }$.

The exponential term in Equation (1) quantifies the relationship between $Z_{\max }$ and $R$, with the freshwater lens thicker with higher rainfall rates. This relationship is based on SUTRA simulation results that used a Holocene $K$ of $50 \mathrm{~m} /$ day, no reef flat plate, and a constant recharge rate, and the $S$, $C$, and $D$ factors are used to scale the result for varying values of Holocene $K$, the presence of the reef flat plate, and time-dependent rainfall. Values of $S$ and $C$ as a function of island width are provided as Figure S1 in Supplementary Materials. For D, values are based on simulations using 1997-1999 rainfall data from the eastern region of the Caroline Islands, wherein the 1998 drought was the most severe on record. The month-by-month $D$ values for both leeward and windward islands are shown in Figure 4. For each island type there are three curves: one for islands $<200 \mathrm{~m}$ in width, one for islands between 200 and $600 \mathrm{~m}$ in width, and one for islands greater than $600 \mathrm{~m}$ in width. These curves mimic the response of the freshwater lens during an El Niño drought, with values decreasing drastically during the drought period and then increasing during the recovery period. To use these curves, the $Z_{\max }$ value is calculated for average rainfall conditions using $Z_{\max }=Z_{L i m} \cdot\left(1-e^{-b R}\right) \cdot S \cdot C$ and then multiplied by each monthly $D$ factor during the 3-year period to obtain a time series of $Z_{\max }$.

The model only estimates the thickness of the freshwater lens at the mid-point of an island cross section, i.e., under the center of the island. Also, the model only is valid for steady conditions, i.e., the thickness and volume of the freshwater lens are not changing in time. Therefore, the model provides long-term average lens thickness under the center of the island, and cannot be used to determine short-term changes in the lens thickness, such as after a strong storm event. The model can be used to estimate the lens thickness during a drought period, as described in the previous paragraph. However, these values of $D$ in Equation (1) are derived from numerical groundwater modeling simulations specific to the climate of the eastern region of the Caroline Islands, and hence are valid only for this region. Values for other regions would need to be found using the same numerical modeling methodology. The model has been tested previously for average lens thickness of islands in the Federated States of Micronesia [19] and in the Republic of Maldives [20].

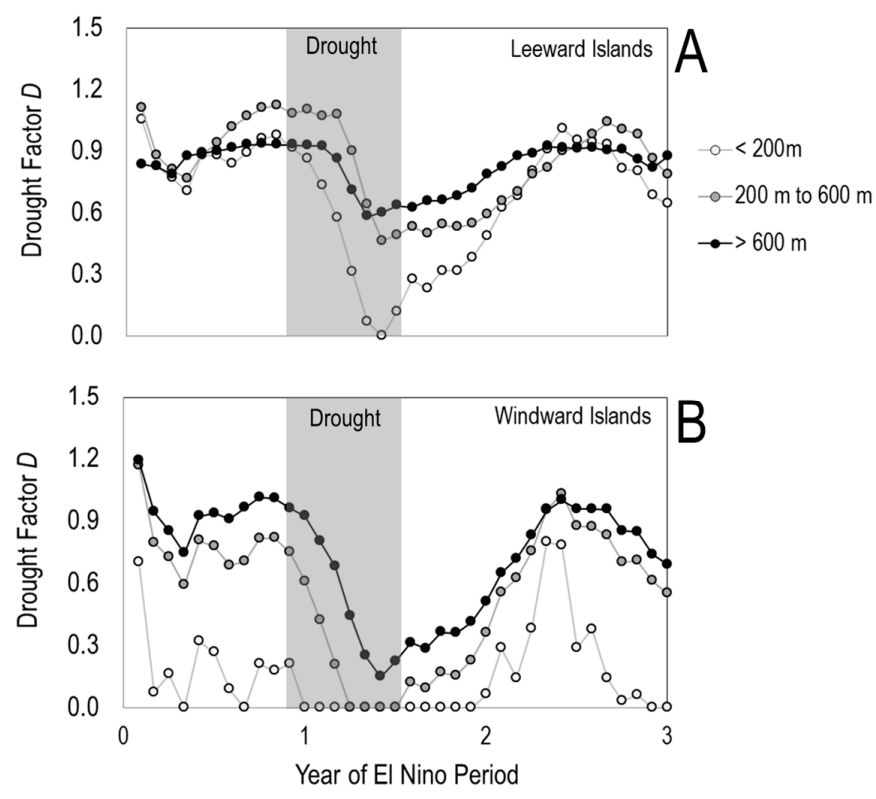

Figure 4. Drought factors $D$ for (A) leeward and (B) windward islands for the algebraic model. These factors are based on SUTRA numerical modeling simulations and are used to scale the average $Z_{\text {max }}$ value provided by the algebraic model. 


\subsection{Marshall Islands Groundwater Availability under Average Rainfall Conditions}

The algebraic model in Equation (1) is applied to the majority of islands of the Marshall Islands to determine the thickness of the freshwater lens under the center of each island under average rainfall conditions. As such, the form $Z_{\max }=Z_{\mathrm{Lim}} \cdot\left(1-e^{-b R}\right) \cdot S \cdot C$ is used. Rainfall $R$ for each island is based on a linear gradient from 0.5 to $4.0 \mathrm{~m}$ /year from the northwest to the southeast of the region. Only islands with a width $\geq 125 \mathrm{~m}$ were included, resulting in 680 islands. Cross-section width $w$ for each island was measured using Google Maps [29]. Holocene $K$ was set to $50 \mathrm{~m} /$ day for leeward islands and $400 \mathrm{~m} /$ day for windward islands [26], with islands located between the leeward and windward side ("mixed" islands) given a value of $200 \mathrm{~m} /$ day [19]. $Z_{T D}$ is set to $17.5 \mathrm{~m}$ for each island, representing the approximate average of depths observed for atoll islands in the Pacific Ocean. The model is corroborated using $Z_{\max }$ values for six islands (Table 1) that span the northwest (NW) to southeast (SE) geographic extent of the Marshall Islands (see Figure 1B).

Table 1. List of available observed freshwater lens thickness for six different islands in the Republic of Marshall Islands. The results of using the algebraic model are presented in the "Model" column.

\begin{tabular}{ccccccc}
\hline Island & Atoll & Location & Width $(\mathbf{m})$ & Observed $(\mathbf{m})$ & Model $(\mathbf{m})$ & Reference \\
\hline Bikini & Bikini & NW & 700 & 2 & 5.8 & {$[21]$} \\
Eneu & Bikini & NW & 500 & 5 & 4.7 & {$[21]$} \\
Enjebi & Enewetak & NW & 986 & 2 & 7.3 & {$[13]$} \\
Kwajalein A-A' & Kwajalein & Central & 600 & 10.7 & 8.1 & {$[12]$} \\
Kwajalein B-B' & Kwajalein & Central & 730 & 9.1 & 10.5 & {$[12]$} \\
Roi-Namur & Kwajalein & Central & 800 & 7 & 6.7 & {$[18]$} \\
Laura & Majuro & SE & 1240 & 14.6 & 17.1 & {$[16]$} \\
Laura A-A & Majuro & SE & 450 & 15.2 & 14.0 & {$[17]$} \\
\hline
\end{tabular}

\subsection{Marshall Islands Groundwater Availability under Extreme Drought Conditions}

After application to average rainfall conditions, the full algebraic model in Equation (1) is used to assess the fluctuation of the freshwater lens during a 3-year period consisting of the El Niño year (Year 1), the drought year (Year 2), and the recovery year (Year 3) using the drought factors shown in Figure 4. The drought factors are assigned to each island based on their position on the atoll (leeward: Figure 4A; windward: Figure 4B), and their cross-section width. As these factors were established for 1997-1999, results will be simulated for that time period. The highest priority and concern is the thinning of a lens during drought, and hence the most crucial result is the minimum $Z_{\text {max }}$ value occurring during the 1997-1999 time period, representing the worst-case scenario of groundwater depletion during a severe drought. The model is applied to several islands for each atoll, resulting in 83 total islands. The model is corroborated using $Z_{\max }$ values for Laura Islands, Majuro Atoll, for which $Z_{\text {max }}$ was measured three to four times at four monitoring wells during the 1998 drought. The locations of the monitoring wells are shown in Figure 2B, and the widths of the four cross sections and the time series data of lens thickness are shown in Table 2.

Table 2. Freshwater lens thickness during the 1998-1999 time period on Laura Island, Majuro Atoll for four different cross sections. See Figure $2 \mathrm{~B}$ for the location of the monitoring wells.

\begin{tabular}{|c|c|c|c|c|}
\hline \multirow{3}{*}{ Date } & \multicolumn{4}{|c|}{ Cross Sections } \\
\hline & $A-A^{\prime}$ & B-B' & D-D' & E-E' \\
\hline & $450 \mathrm{~m}$ & $750 \mathrm{~m}$ & $1200 \mathrm{~m}$ & $750 \mathrm{~m}$ \\
\hline 1 January 1998 & 15.2 & - & - & - \\
\hline 8 June 1998 & 7.9 & 11.3 & 14.6 & 11.3 \\
\hline 28 August 1998 & 8.2 & 11.9 & 15.8 & 13.7 \\
\hline 14 January 1999 & 9.8 & 12.5 & 17.1 & 13.7 \\
\hline
\end{tabular}




\section{Results and Discussion}

\subsection{Average Rainfall Conditions}

Results of testing the algebraic model against measured $Z_{\max }$ data are shown in Figure 5 using a 1:1 plot of observed vs. calculated $Z_{\max }$. The match between the observed and calculated values is good, with a Pearson product-moment correlation coefficient $(R)$ of 0.87 . The model over-estimates the lens thickness for Bikini (5.8 to $2.0 \mathrm{~m}$ ) and Enjebi $(7.3$ to $2.0 \mathrm{~m})$ islands. Peterson mentions that Bikini has extremely high ET rates due to a cover of thick vegetation, and as a result has a thinner lens $(2.0 \mathrm{~m})$ than Eneu (5.0 m) (see Table 1), even though it is $25 \%$ wider [21]. Thus, although the model overall provides satisfactory results, care should be taken when applying it to an individual island without field data. Results from this study thus are intended to provide a general assessment for the Marshall Islands and not island-specific quantities.

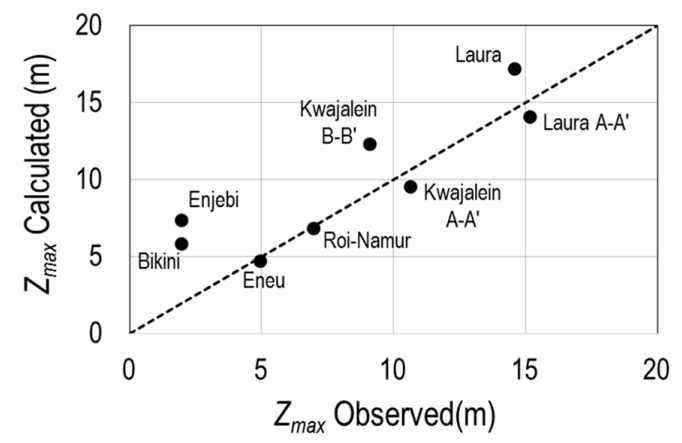

Figure 5. Plot of observed vs. simulated $Z_{\text {max }}$ for islands with observation data (see Table 1). Each data point is labeled with the observed lens thickness.

Results for each of the 680 islands, along with the algebraic model parameter values used, is contained in Table S1 in Supplementary Materials. Full results are shown graphically in Figure 6A, with $Z_{\max }(\mathrm{m})$ plotted against island width $(\mathrm{m})$ for each island. The islands are divided into Leeward, Mixed, and Windward. The lens is thickest for leeward islands due to the lowest Holocene $K$ value (50 m/day), but lens thickness is limited for larger islands ( $>750 \mathrm{~m}$ in width) by the Thurber Discontinuity. Both mixed islands and windward islands show a linear trend between island width and $Z_{\text {max }}$, with windward islands having the thinnest lenses because of the high Holocene $K$ (400 m/day). The influence of annual rainfall rate is shown in Figure 6B, which shows lens thickness for islands located in the Northern part of the region (low rainfall) and in the Southern part of the region (high rainfall). Lens thickness is only limited for larger islands $(>750 \mathrm{~m})$ with high rainfall rates. Large islands in the Northern region do not have lenses that extend to the Thurber Discontinuity.

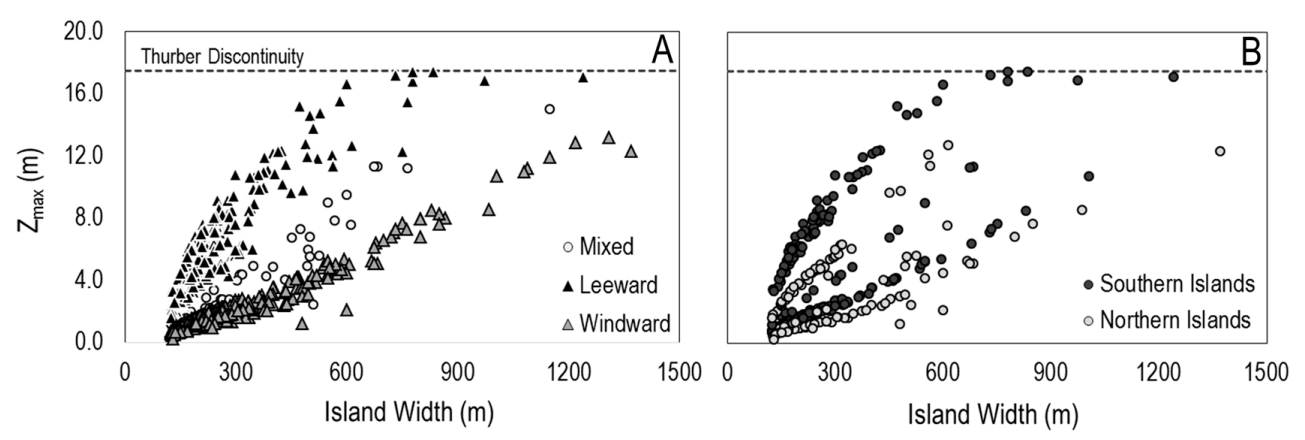

Figure 6. (A) Lens thickness $\left(Z_{\max }\right)$ for the 680 islands in the Republic of Marshall Islands, graphed according to island width and by position of each island on the atoll (windward, leeward, mixed); (B) Lens thickness $\left(Z_{\max }\right)$ for the islands located in the north and south of the RMI geographic region. 
Overall, average lens thickness for the 680 islands is $3.6 \mathrm{~m}$, ranging from 0.15 to $17.4 \mathrm{~m}$. A frequency distribution of $Z_{\text {max }}$ is shown in Figure $7 \mathrm{~A}$. About $55 \%$ of all islands have a lens thickness less than $2.5 \mathrm{~m}$, and only $30 \%$ of islands have a lens thicker than $4.5 \mathrm{~m}$, demonstrating the extreme fragility of groundwater resources in the Marshall Islands. The average lens thickness for each atoll, i.e., averaging the lens thickness of each island for a given atoll, is shown in Figure 7B. The names of the atolls in Figure 7B are listed from left to right according to their location in the northwest-to-southeast direction, which corresponds to the direction of increasing average annual rainfall. As such, results in Figure 7B show that rainfall is not the dominant factor in determining lens thickness, with island width and Holocene $K$ also playing a key role.
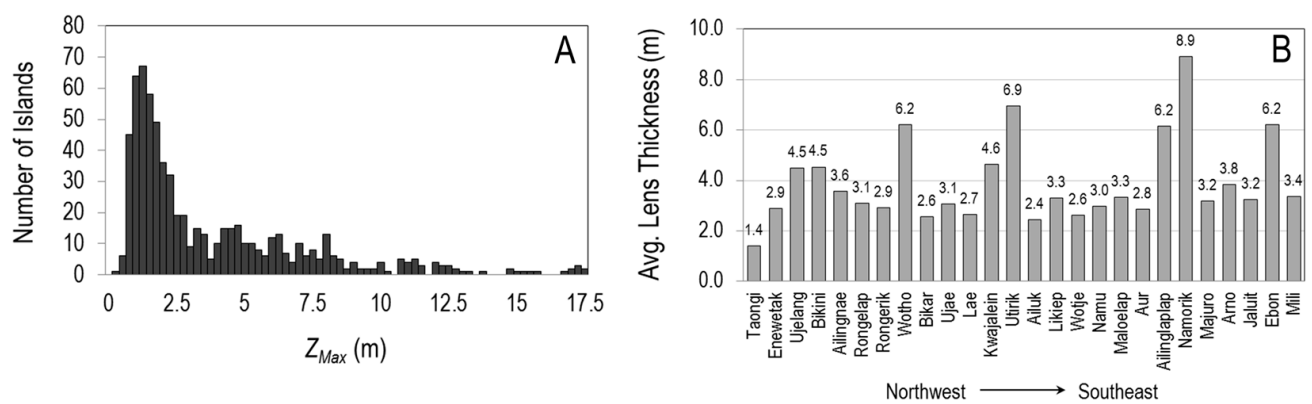

Figure 7. (A) Frequency distribution of $Z_{\max }$ under average rainfall conditions for the 680 islands; (B) Average lens thickness $\left(Z_{\max }\right)$ for each atoll in the RMI. Island values are shown according to their location in the northwest-to-southeast direction, which corresponds to the direction of increasing average annual rainfall.

\subsection{Extreme Drought Conditions}

Figure 8 shows the results of applying the algebraic model to the four cross sections on Laura Island. For each cross section, the simulated values from the algebraic model (solid line) track very well the observed lens thickness (gray dots) at the monitoring times. Particularly for cross section A- $\mathrm{A}^{\prime}$ (Figure 8A), the model is able to accurately simulate the pre-drought value of $15.2 \mathrm{~m}$ and then the rapid thinning of the lens during the first half of 1998. For each cross section, the model is able to track the increase in lens thickness during the latter part of 1998 and the first half of 1999.

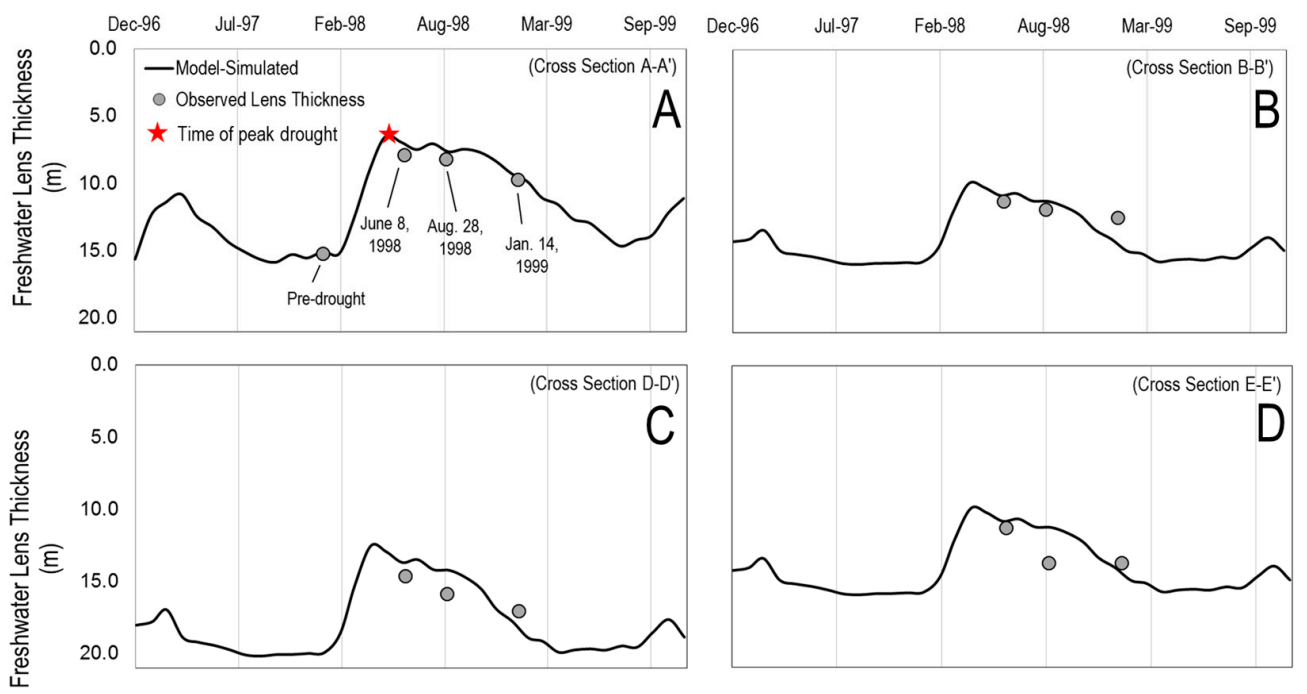

Figure 8. Observed and simulated lens thickness at the four monitoring well locations (see Figure 2B) located along (A) cross section A-A'; (B) cross section B-B'; (C) cross section D-D'; and (D) cross section E-E'. 
$Z_{\max }$ under both average rainfall conditions and under drought conditions are shown in Figure 9 for the 83 islands assessed. Results for Leeward, Windward, and Mixed islands are shown in Figure 9, respectively. For each island, the drought value corresponds to $Z_{\max }$ at the peak of the drought, as shown by the red star in Figure 8A. Similar to the decrease in lens thickness during the drought for Laura Island (Figure 8), each island experiences a large decrease in lens thickness from pre-drought to the peak of the drought. The decrease is most significant for windward islands (Figure 9B) and mixed islands (Figure 9C). For all island types, fresh groundwater generally is completely depleted at the peak of drought for small islands $(<400 \mathrm{~m})$.

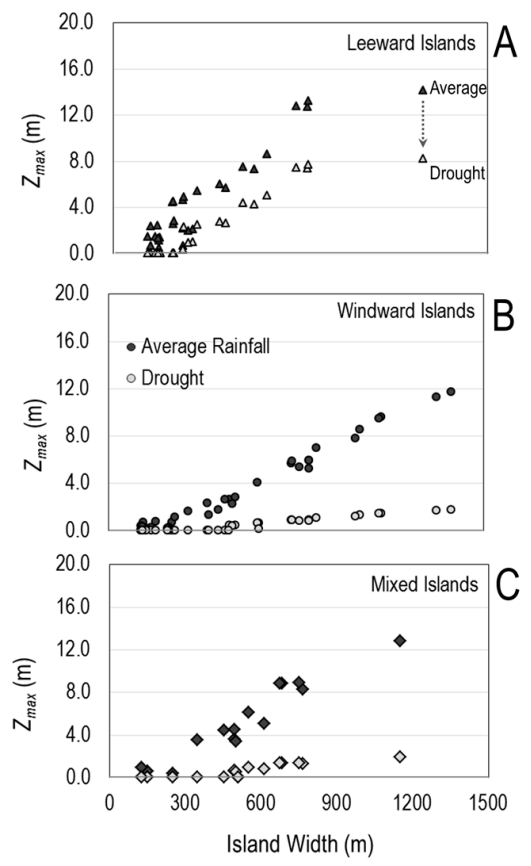

Figure 9. $Z_{\max }(\mathrm{m})$ during average rainfall conditions (dark data points) and severe drought conditions (light data points) for islands positioned on the (A) leeward; (B) windward; and (C) mixed sides of an atoll, plotted against island width. The depletion is most severe for windward islands (B) and mixed islands (C). In (A), the decrease from average to drought conditions for an island is shown with a dotted gray arrow.

Groundwater depletion during drought is shown further in Figure 10A, which shows the percent decrease in $Z_{\max }$ from pre-drought to the peak of the drought for each of the 83 islands. For small islands $(<400 \mathrm{~m})$, percent decrease generally is greater than $50 \%$, no matter the island type. Larger islands are less affected, with percent decrease generally less than $20 \%$ for islands with widths greater than $800 \mathrm{~m}$. Figure $10 \mathrm{~B}$ shows percent decrease against $Z_{\max }$ under average rainfall conditions to show islands that are "Highly Vulnerable" and "Moderately Vulnerable" i.e., a lens thickness during the peak of the drought that is less than 3 and $4.5 \mathrm{~m}$, respectively. These results again demonstrate the extreme fragility of groundwater resources for the Marshall Islands. Several larger islands can maintain a freshwater lens sufficient to sustain the island population during a major drought, but the majority have inefficient groundwater resources. It is likely the conditions shown in Figures 9 and 10 are currently being experienced during the present 2016 drought. These results can help water resources mangers plan for future droughts and, assuming that rainfall during the 2016-2017 time period will coincide with the recovery period of 1999 after the 1998 drought, can assist managers and government agencies in forecasting groundwater availability for the coming year.

Results are similar to other atoll nations in the Pacific Ocean. For example, modeling results for atoll islands in the Federated States of Micronesia found that out of 105 inhabited islands, only six would have adequate groundwater to sustain the local population during a drought similar to the 
one experienced in 1998 [19]. Other studies focused on low coral island freshwater resources have emphasized the major impact of drought on the freshwater lens of atoll islands [5,7,30]. For example, White provides data for droughts in South Tarawa, Kiribati, with the conclusion that major droughts occur on average every 6 years and cause significant depletion of the freshwater [5]. For example, a decrease in lens thickness from $18 \mathrm{~m}$ to $6 \mathrm{~m}$ was experienced over a 6-month period in 1994-1995 [30].
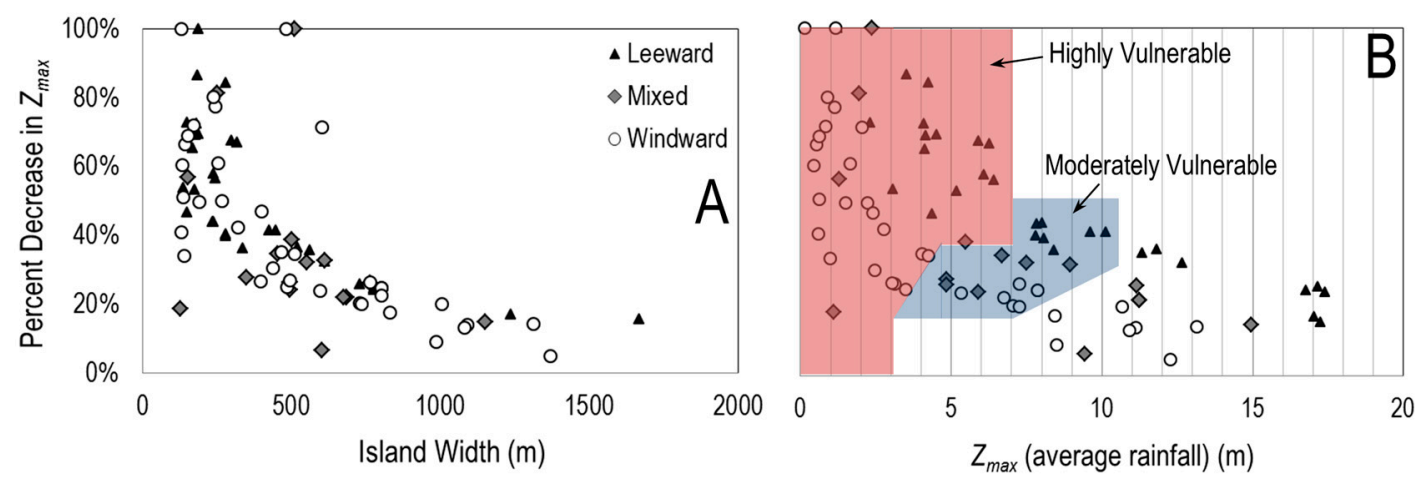

Figure 10. Percent decrease of $Z_{\max }$ during a major drought, plotted against (A) island width and (B) $Z_{\text {max }}$ during average rainfall conditions. (B) shows the set of islands that are "Highly" and "Moderately" vulnerable to drought, based on a criterion of $Z_{m a x} \geq 3 \mathrm{~m}$ during the peak of the drought.

\section{Summary and Concluding Remarks}

Groundwater resources of small coral islands are critical for the survival of the local population, particularly during drought conditions when stored rainwater is exhausted. This study provides an estimate of groundwater availability for atoll islands in the Marshall Islands, a nation acutely and currently affected by severe drought. This study considers groundwater conditions under both average seasonal rainfall and drought conditions. Calculations are performed using an algebraic model designed for atoll islands, and accounts for precipitation, island width, presence of a reef flat plate, hydraulic conductivity of the Holocene-age sandy aquifer, and the depth to the contact between the sand aquifer and the lower limestone aquifer [27]. The model is applied to 680 islands for average seasonal rainfall and to 83 islands for drought conditions, with the 1997-1999 rainfall data used for the latter to replicate the impact of the 1998 severe drought. Model results are tested against islands in the Marshall Islands that have lens thickness data.

Results demonstrate the extreme fragility of groundwater resources of the islands in the Republic of Marshall Islands. Average lens thickness for the 680 islands is $3.6 \mathrm{~m}$, ranging from 0.15 to $17.4 \mathrm{~m}$, with $55 \%$ of all islands with a lens thickness less than $2.5 \mathrm{~m}$ and only $30 \%$ of islands with a lens thicker than $4.5 \mathrm{~m}$. Islands located on the windward side of an atoll have the thinnest lenses due to the high permeability of the Holocene aquifer sediments. During drought, the groundwater on most small islands ( $<300 \mathrm{~m}$ in width) is completely depleted, with only large islands $(>800 \mathrm{~m})$ maintaining a sizeable freshwater lens for use by the local population. Of the 83 islands assessed for lens thickness during a severe drought, just over half (54\%) are classified as "Highly Vulnerable" to drought, $23 \%$ are classified as "Moderately Vulnerable" to drought, and the remainder are only slightly affected by drought.

Besides the method used herein being transferrable to other atoll nations to determine the impact of drought, results can be used by water resources managers to determine the effect of severe droughts on groundwater in the Marshall Islands and assist in determining upcoming emergency situations during El Niño periods.

Supplementary Materials: The following are available online at www.mdpi.com/2073-4441/9/1/41/s1.

Acknowledgments: This study was inspired to raise awareness for the imminent threat that approaches residents of the Republic of Marshall Islands. Many other island nations face the same threats of drought and sea level rise, 
of which death may be the result. The authors have quantified this threat in one region, and hope to aid all those who live on the small islands of our world. A special thanks to anonymous reviewers, and to the families of both the reviewers for their love and moral support.

Author Contributions: Brandon L. Barkey and Ryan T. Bailey conceived and designed the experiments; Brandon L. Barkey performed the experiments; Brandon L. Barkey gathered and analyzed the data; Ryan T. Bailey reviewed the data results; Ryan T. Bailey contributed materials and analysis tools; Brandon L. Barkey wrote the paper; Ryan T. Bailey reviewed and edited the paper.

Conflicts of Interest: The authors declare no conflict of interest.

\section{References}

1. Pernetta, J.C. Impacts of climate change and sea-level rise on small island states. National and international responses. Glob. Environ. Chang. 1992, 2, 19-31. [CrossRef]

2. Roy, P.; Connell, J. Climate change and the future of atoll states. J. Coast. Res. 1991, 7, 1057-1075.

3. White, I.; Falkland, T.; Perez, P.; Dray, A.; Metutera, T.; Metai, E.; Overmars, M. Challenges in freshwater management in low coral atolls. J. Clean. Prod. 2007, 15, 1522-1528. [CrossRef]

4. Woodroffe, C.D. Reef-island topography and the vulnerability of atolls to sea-level rise. Glob. Planet. Chang. 2008, 62, 77-96. [CrossRef]

5. White, I.; Falkland, T.; Scott, D. Droughts in Small Coral Islands: Case Study, South Tarawa, Kiribati; Technical Documents in Hydrology No. 26; UNESCO International Hydrologic Programme: Paris, France, 1999.

6. Burns, W.C.G. The impact of climate change on Pacific island developing countries in the 21st century. In Climate Change in the South Pacific: Impacts and Responses in Australia, New Zealand, and Small Island States; Gillespie, A., Burns, W.C.G., Eds.; Springer: Berlin/Heidelberg, Germany, 2000; pp. 233-250.

7. White, I.; Falkland, T. Management of freshwater lenses on small Pacific islands. Hydrogeol. J. 2010, 18, 227-246. [CrossRef]

8. Taboroši, D.; Martin, M. Pakein Atoll: Freshwater Resourcesand Their Usage, State, and Infrastructure; Island Research \& Eduation Initiative: Palikir, Federated States of Micronesia, 2011.

9. Pacific RISA. Available online: http://www.pacificrisa.org/places/republic-of-the-marshall-islands/ (accessed on 22 September 2015).

10. Cox, D.C. The Hydrology of Arno Atoll, Marshall Islands; Atoll Research Bulletin 8; The Pacific Science Board: Washington, DC, USA, 1951; pp. 1-29.

11. Arnow, T. The Hydrology of the Northern Marshall Islands; Atoll Research Bulletin 8; The Pacific Science Board: Washington, DC, USA, 1954; pp. 1-29.

12. Hunt, C.D., Jr.; Peterson, F.L. Groundwater Resources of Kwajalein Island, Marshall Islands; Technical Report No. 126; Water Resources Research Center, University of Hawaii: Honolulu, HI, USA, 1980.

13. Buddemeier, R.W.; Holladay, G. Atoll hydrology: Island characteristics and their relationship to diagenesis. In Proceedings of Third International Coral Reef Symposium Vol. 2: Geology; Rosenstiel School of Marine and Atmospheric Science: Miami, FL, USA, 1977.

14. Wheatcraft, S.W.; Buddemeier, R.W. Atoll island hydrology. Ground Water 1981, 19, 311-320. [CrossRef]

15. Herman, M.E.; Wheatcraft, S.W. Groundwater Dynamics Investigation of Enjebi Island, Enewetak Atoll: An Interpretive Computer Model Simulation, Finite Elements in Water Resources; Springer: New York, NY, USA, 1984; pp. 133-142.

16. Hamlin, S.N.; Anthony, S.S. Ground-Water Resources of the Laura Area, Majuro Atoll, Marshall Islands; USGS Water Resources Investigation Report 87-4047; U.S. Geological Survey: Reston, VA, USA, 1987.

17. Presley, T.K. Effects of the 1998 Drought on the Freshwater Lens in the Laura Area, Majuro Atoll, Republic of the Marshall Islands; USGS Scientific Investigations Report 2005-5098; U.S. Geological Survey: Reston, VA, USA, 2005.

18. Gingerich, S.B. Numerical Simulation of the Freshwater Lens on Roi-Namur Island, Kwajalein Atoll. Master's Thesis, University Hawaii, Honolulu, HI, USA, 1992; p. 110.

19. Bailey, R.T.; Jenson, J.W.; Taborosi, D. Estimating the freshwater lens thickness of atoll islands in the Federated States of Micronesia. Hydrogeol. J. 2013, 21, 441-457. [CrossRef]

20. Bailey, R.T.; Khalil, A.; Chatikavanij, V. Estimating Current and Future Groundwater Resources of the Maldives. J. Am. Water Resour. Assoc. 2014, 51, 112-122. [CrossRef] 
21. Peterson, F.L. Hydrogeology of the Marshall Islands. In Geology and Hydrogeology of Carbonate Islands. Development in Sedimentology; Elsevier Science: Amsterdam, The Netherlands, 1997; pp. 611-666.

22. Anthony, S.S. Hydrogeology of selected islands of the Federated States of Micronesia. In Geology and Hydrogeology of Carbonate Islands, Developments in Sedimentology 54; Vacher, H.L., Quinn, T., Eds.; Elsevier Science: Amsterdam, The Netherlands, 1997; pp. 693-706.

23. Buddemeier, R.W.; Oberdorfer, J.A. Hydrogeology of Enewetak Atoll. In Geology and Hydrogeology of Carbonate Islands, Developments in Sedimentology 54; Vacher, H.L., Quinn, T., Eds.; Elsevier Science: Amsterdam, The Netherlands, 1997; pp. 667-692.

24. Ayers, J.F.; Vacher, H.L. Hydrogeology of an atoll island: A conceptual model from detailed study of a Micronesian example. Ground Water 1986, 24, 185-198. [CrossRef]

25. Spennemann, D.H.R. Non-traditional settlement patterns and typhoon hazard on contemporary Majuro Atoll, Republic of the Marshall Islands. Environ. Manag. 1996, 20, 337-348. [CrossRef]

26. Bailey, R.T.; Jenson, J.W.; Olsen, A.E. Numerical Modeling of Atoll Island Hydrogeology. Ground Water 2009, 47, 184-196. [CrossRef] [PubMed]

27. Bailey, R.T.; Jenson, J.W.; Olsen, A.E. Estimating the ground water resources of atoll islands. Water 2010, 2, 1-27. [CrossRef]

28. Voss, C.I.; Provost, A.M. SUTRA, A Model for Saturated-Unsaturated Variable-Density Ground-Water Flow with Solute or Energy Transport; USGS Water-Resources Investigations Report 02-4231; U.S. Geological Survey: Reston, VA, USA, 2003; pp. 1-250.

29. Google Maps. Available online: https://www.google.com/maps/place/Marshall+Islands/@11.3249945, $166.7016573,67453 \mathrm{~m} /$ (accessed on 1 October 2015).

30. White, I.; Falkland, T.; Metutera, T.; Metai, E.; Overmars, M.; Perez, P.; Dray, A. Climatic and human influences on groundwater in low atolls. Vadose Zone J. 2007, 6, 581-590. [CrossRef]

(C) 2017 by the authors; licensee MDPI, Basel, Switzerland. This article is an open access article distributed under the terms and conditions of the Creative Commons Attribution (CC-BY) license (http://creativecommons.org/licenses/by/4.0/). 